\title{
ANALISIS FISIS MEMBRAN BIOFILTER ROKOK DENGAN VARIASI DAUN, BIJI DAN KULIT DELIMA
}

Oleh:

\author{
Umaiyatus Syarifah $^{1}$, Ririn Mega $S^{2}$., Muthmainnah ${ }^{3}$, Agus Mulyono ${ }^{4}$
}

\begin{abstract}
ABSTRAK: Analisis fisis membrane biofilter rokok telah dilakukan untuk mengetahui kerapatan dan porositas. Membrane biofilter terbuat dari variasi daun delima, biji delima dan kulit delima. Variasi massa yang digunakan pada masing-masing bahan delima adalah 0.7 gram, 0.8 gram, 0.9 gram dan 1 gram. Matriks yang digunakan pada pembuatan biofilter berbahan delima adalah polyethilene glikol (PEG). Data pengujian kerapatan membran pada biofilter berbahan daun delima terbesar adalah $1.532 \mathrm{~g} / \mathrm{cm}^{3}$ dengan komposisi 0.7 gram. Pada biofilter yang menggunakan biji delima kerapatan paling tinggi bernilai $1.491 \mathrm{~g} / \mathrm{cm}^{3}$ dengan komposisi 0.7 gram. Biofilter yang menggunakan kulit delima memiliki kerapatan terbesar pada komposisi 1 gram dengan nilai $1,436 \mathrm{~g} / \mathrm{cm}^{3}$. Nilai kerapatan tertinggi antara membran biofilter berbahan daun delima, biji delima dan kulit delima adalah membran biofilter daun delima dengan variasi 0.7 gram. Porositas pada daun delima memiliki nilai terkecil pada variasi massa 0.7 gram dengan nilai porositas $8.67 \%$. pada biji delima porositas terkecil adalah $4.10 \%$ dengan variasi massa 0.7 gram. Membran biofilter dengan kulit delima memiliki porositas terkecil pada variasi massa 0.7 gram dengan nilai $76.72 \%$. Nilai porositas terkecil antara membran biofilter berbahan daun delima, biji delima dan kulit delima adalah membran biofilter biji delima dengan variasi 0.7 gram.
\end{abstract}

Kata Kunci: Analisis Fisis; biofilter; Delima; Membrane; Composit; Rokok; Asap Rokok; Porositas.

\begin{abstract}
Physical analysis of cigarette biofilter membrane have been conducted to determine the porosity and density. Membrane bio-filter was made of pomegranate leaf, pomegranate seeds and pomegranate skin on different composition. The used mass variations of pomegranate were $0.7 \mathrm{~g} ; 0.8 \mathrm{~g} ; 0.9 \mathrm{~g}$; and $1 \mathrm{~g}$. Matrix used in the manufacture of biofilter membrane was polyethylene glycol (PEG). The highest density of pomegranate leaves, pomegranate seeds and pomegranate skin biofilter were $1.532 \mathrm{~g} / \mathrm{cm}^{3}$ contained composition 0.7 $\mathrm{g}$ and $1.491 \mathrm{~g} / \mathrm{cm} 3$ contained $0.7 \mathrm{~g}$ and $1.436 \mathrm{~g} / \mathrm{cm} 3$ contained $1 \mathrm{gram}$ respectively. Meanwhile its smalest porosities were $8.67 \% ; 4.10 \%$ and $76.72 \%$ respectively. It was concluded that pomegranate seed biofilter is the best biofiter memrane due to the smallnessof porosity
\end{abstract}

Keyword: Physical analysis; biofilter; pomegranate; membrane; composite; cigarettes; Cigarette Smoke; Porosity.

1,3 dan ${ }^{4}$ Staf Pengajar Jurusan Fisika Fakultas Sains dan Teknologi, Universitas Islam Negeri Maulana Malik Ibrahim Malang

2 Mahasiswa Jurusan Fisika Fakultas Sains dan Teknologi Universitas Islam Negeri Maulana Malik Ibrahim Malang 


\section{PENDAHULUAN}

Merupakan seuatu aktivitas membakar gulungan tembakau dan menghisap asapnya. Merokok banyak dilakukan dan menjadi tradisi di indonesia baik di kota atau didesa. Kebiasaan merokok masyarakat Indonesia yang dilakukan di tempat terbuka terbukti mampu memberikan suatu dorongan ketertarikan seseorang yang tidak merokok atau belum merokok untuk mencoba kenikmatan suatu rokok. Bahkan saat ini, merokok sudah dianggap sebagai suatu sarana penyambung dalam pergaulan. Kebiasaan merokok sambil berbincang-bincang dengan teman, saudara atau keluarga sudah seakan menjadi tradisi sebagian masyarakat yang sulit ditinggalkan.

Pada dasarnya bahaya rokok muncul karena radikal bebas yang di bawa oleh asapnya. Radikal bebas adalah sekelompok bahan kimia baik berupa atom maupun molekul yang memiliki elektron tidak berpasangan pada lapisan luarnya. Pemanfaatan bahan alam dimungkinkan bisa mengurangi bahaya radikal bebas pada asap rokok. Pada hasil penelitian tentang biofilter berbahan serbuk cangkang kepiting dan kopi untuk menangkap radikal bebas asap rokok (kretek) mampu menyerap beberapa jenis dugaan radikal bebas.

Buah delima (Punica Granatum Linn) merupakan salah satu sumber antioksidan dari tumbuh-tumbuhan dengan kandungan polifenol dan antosianin yang cukup tinggi. Pigmen antosianin berfungsi untuk warna merah, ungu dan biru dari buah, sayuran dan bunga. Antosianin merupakan salah satu antioksidan kuat yang mampu mencegah berbagai kerusakan akibat stress oksidatif sehingga mampu melindungi sel dari radikal bebas (1). Radikal bebas pada asap rokok dapat dikurangi dengan menggunakan filter yang tepat.

Penelitian ini membahas tentang pembuatan biofilter dengan menggunakan daun delima, biji delima dan kulit delima. Analisis fisis dilakukan pada masing-masing bahan yang digunakan dengan menerapkan pula variasi massa. Matriks pada pembuatan membran biofilter yang digunakan adalah poliethiel glicol (PEG). Kerapatan dan porositas akan dihitung sehingga dapat diketahui bahan mana yang lebih aktif dapat menangkap radikal bebas.

Pengertian bahan komposit berarti terdiri dari dua atau lebih bahan yang berbeda yang digabung atau dicampur secara makroskopis menjadi suatu bahan yang berguna (2), karena bahan komposit merupakan bahan gabungan secara makro, maka bahan komposit dapat didefinisikan sebagai suatu sistem material yang tersusun dari campuran/kombinasi dua atau lebih unsur-unsur utama yang secara makro berbeda di dalam bentuk dan atau komposisi material yang pada dasarnya tidak dapat dipisahkan (3). Bahan komposit secara umum terdiri dari penguat dan matrik.Penguat komposit pada umumnya mempunyai sifat kurang ulet tetapi lebih kaku serta lebih kuat.

Membran ialah sebuah penghalang selektif antara dua fasa. Membran memiliki ketebalan yang berbeda-beda, ada yang tebal dan ada juga yang tipis serta ada yang homogen dan yang heterogen. Ditinjau dari bahannya membran terdiri dari bahan alami dan bahan sintetis. Bahan alami adalah bahan yang berasal dari alam misalnya pulp dan kapas, sedangkan bahan sintetis dibuat dari bahan kimia, misalnya polimer. Membran berfungsi memisahkan material berdasarkan ukuran dan bentuk molekul, menahan 
komponen dari umpan yang mempunyai ukuran lebih besar dari pori-pori membran dan melewatkan komponen yang mempunyai ukuran yang lebih kecil. Larutan yang mengandung komponen yang tertahan disebut konsentrat dan larutan yang mengalir disebut permeat. Filtrasi dengan menggunakan membran selain berfungsi sebagai sarana pemisahan juga berfungsi sebagai sarana pemekatan dan pemurnian dari suatu larutan yang dilewatkan pada membran tersebut (4).

Penambahan bahan aditif pada membran berguna untuk meningkatkan atau memodifikasi sifat-sifat mekanik, kimia, dan fisik membran. Polietilen glikol (PEG) merupakan salah satu diantara zat aditif yang sering ditambahkan pada pembuatan membran yang berfungsi sebagai porogen untuk meningkatkan keteraturan bentuk poripori pada membran sehingga struktur pori lebih rapat dan membran yang dihasilkan semakin bagus.

Polietilen glikol (PEG) adalah salah satu bahan aditif pada membran berguna untuk meningkatkan atau memodifikasi sifat-sifat mekanik, kimia, dan fisik membran. Polietilen glikol (PEG) merupakan salah satu diantara zat aditif yang sering ditambahkan pada pembuatan membran yang berfungsi sebagai porogen untuk meningkatkan keteraturan bentuk pori-pori pada membran sehingga struktur pori lebih rapat dan membran yang dihasilkan semakin bagus. PEG merupakan senyawa hasil kondensasi dari oksietilen dan air dengan rumus molekul $\mathrm{H}\left(\mathrm{OCH}_{2} \mathrm{CH}_{2}\right) \mathrm{nOH}$, dimana $\mathrm{n}$ merupakan bilangan (jumlah) ratarata pengulangan grup oksietilen mulai dari 4 sampai 180 .

Delima mempunyai kandungan zat gizi dan fitonutrien sebagai berikut: Provitamin A (karotenoid), vitamin C, vitamin B1 dan vitamin B2, mineral besi dan potasium atau kalim, polifenol (3 kali lebih banyak dari teh hijau) dan flavonoid (Emma, 2007). Buah masak : $78 \%$ air, 14,5\% karbohidrat, 1,6\% protein, 0,1\% lemak, 5,1\% serabut, 0,7\% mineral, gula glukosa, asid sitrik, asid borik dan vitamin C. Daun, kulit kayu, kulit buah dan akar: tanin (kulit kayu mengandung $28 \%$ tanin, warna kuning pada kulit buah ialah asid gallotonik dan kulit buah masak yang dikeringkan mengandung $26 \%$ tanin) (5). Kulit batang maupun kulit akar mengandung senyawa-senyawa alkaloid, antara lain alkaloid pelletierin. Selain itu, kulit batang atau kulit akar juga mengandung zat penyamak (6).

Pembuatan biofilter dilakukan dengan beberapa proses. Daun delima, biji delima dan kulit delima dijemur hingga kering kemudian ditumbuk sampai halus dan menjadi serbuk. Serbuk daun delima, biji delima dan kulit delima diayak menggunakan ayakan 200 mesh. Serbuk daun delima, kulit delima dan buah delima ditimbang dengan masing-masing bahan 0.7 gram, 0.8 gram, 0.9 gram dan 1 gram. Masing-masing variasi komposisi Serbuk daun delima, kulit delima dan buah delima dicampur dengan polietilen glikol (PEG) $0.3 \mathrm{ml}$. Campuran dari masing-masing bahan tersebut dicetak dalam selang pipa berdiameter 0.7 $\mathrm{cm}$ dan panjang $2 \mathrm{~cm}$. Membran komposit didiamkan sampai padat dan kering kemudian dilepas dari cetakan dan di oven dengan menggunakan suhu $105^{\circ} \mathrm{C}$ selama 20 menit.

Analisis fisis yang dilakukan pada penelitian ini adalah kerapatan dan porositas membran biofilter. Perhitungan kerapatan dilakukan dengan menghitung massa dan volum membran. Perhitungan porositas dilakukan dengan menimbang massa kering dan massa basah serta volume dari membran biofilter berbahan delima. 


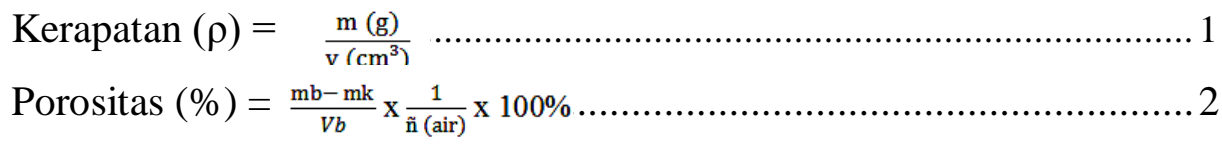

\section{HASIL DAN PEMBAHASAN}

Hasil pengujian kerapatan pada membran biofilter dengan daun delima ditunjukkan oleh tabel 1. Kerapatan terbesar membran biofilter dengan terdapat pada komposisi variasi daun delima 0.7 gram dengan nilai kerapatan $1,532 \mathrm{~g} / \mathrm{cm}^{3}$. Pengujian kerapatan pada membran biofilter berbahan biji delima ditunjukkan oleh tabel 2. Hasil kerapatan terbesar pada membran biofilter berbahan biji delima adalah $1,491 \mathrm{~g} / \mathrm{cm}^{3}$ dengan komposisi variasi biji delima 0,7 gram. Hasil pengujian yang dilakukan pada membran biofilter dengan bahan kulit delima ditunjukkan pada tabel 3. Tabel menunjukkan bahwa membran biofilter variasi kulit delima 1 gram memiliki nilai kerapatan terbesar dengan nilai $1,436 \mathrm{~g} / \mathrm{cm}^{3}$.

Tabel 1. Hasil pengujian kerapatan pada membran biofilter daun delima

\begin{tabular}{cccc}
\hline Membran $(\mathrm{g})$ & $\mathrm{m}(\mathrm{g})$ & $\mathrm{v}\left(\mathrm{cm}^{3}\right)$ & $\rho\left(\mathrm{g} / \mathrm{cm}^{3}\right)$ \\
\hline 0.7 & 1.06 & 0.692 & 1.532 \\
0.8 & 1.08 & 1.055 & 1.023 \\
0.9 & 1.11 & 1.105 & 1.004 \\
1 & 1.11 & 1.155 & 0.961 \\
\hline
\end{tabular}

Tabel 2. Hasil pengujian kerapatan pada membran biofilter biji delima

\begin{tabular}{cccc}
\hline Membran $(\mathrm{g})$ & $\mathrm{m}(\mathrm{g})$ & $\mathrm{v}\left(\mathrm{cm}^{3}\right)$ & $\rho\left(\mathrm{g} / \mathrm{cm}^{3}\right)$ \\
\hline 0.7 & 1.09 & 0.731 & 1.491 \\
0.8 & 1.13 & 0.846 & 1.335 \\
0.9 & 1.14 & 0.923 & 1.235 \\
1 & 1.16 & 1.205 & 0.962 \\
\hline
\end{tabular}

Tabel 3. Hasil pengujian kerapatan pada membran biofilter kulit delima

\begin{tabular}{cccc}
\hline Membran $(\mathrm{g})$ & $\mathrm{m}(\mathrm{g})$ & $\mathrm{v}\left(\mathrm{cm}^{3}\right)$ & $\rho\left(\mathrm{g} / \mathrm{cm}^{3}\right)$ \\
\hline 0.7 & 1.10 & 0.769 & 1.431 \\
0.8 & 1.14 & 0.807 & 1.412 \\
0.9 & 1.20 & 0.846 & 1.418 \\
1 & 1.27 & 0.884 & 1.436 \\
\hline
\end{tabular}

Perbandingan kerapatan antara membran biofilter berbahan daun delima, biji delima dan kulit delima datunjukkan oleh gambar 1. Gambar ini menunjukkan bahwa kerapatan terbesar terletak pada membran biofilter dengan bahan daun delima dengan variasi massa 0.7 gram. Perbedaan ini disebabkan oleh komposisi yang terkandung dalam bahan yang membentuk membran biofilter juga berbeda. Semakin besar kerapatan membran biofilter makan akan semakin baik karena dapat menangkap radikal bebas semakin banyak. 


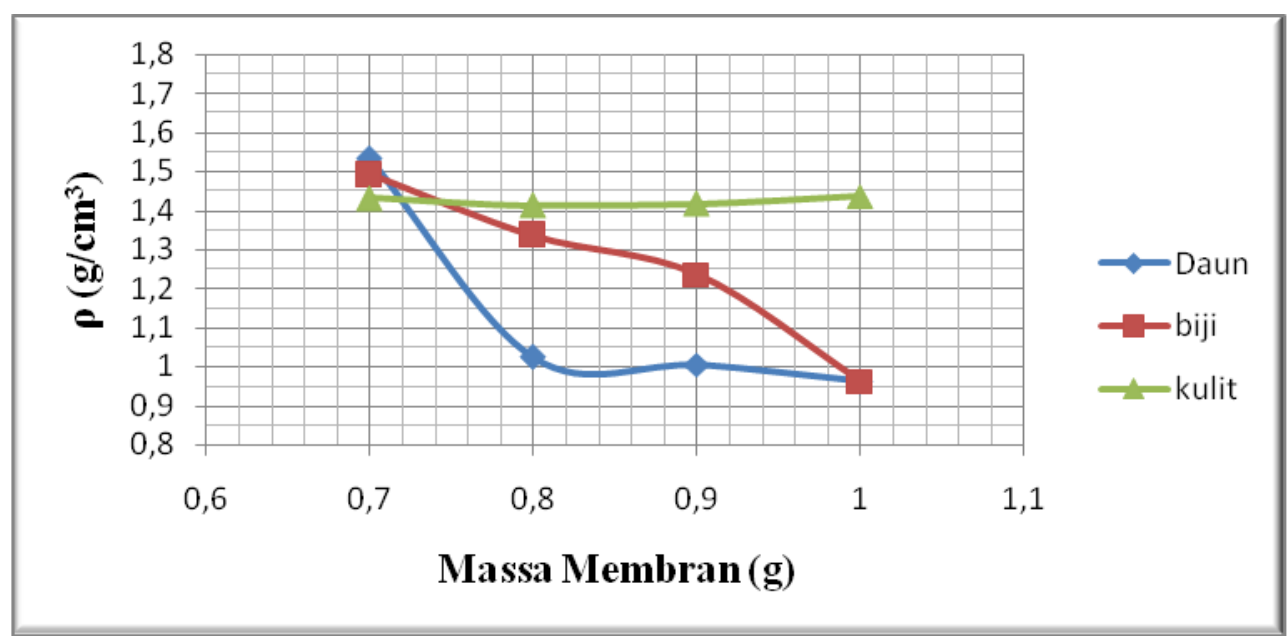

Gambar 1. Perbandingan nilai kerapatan membran biofilter berbahan daun delima, biji delima dan kulit delima.

Pengujian porositas yang telah dilakukan pada membran biofilter berbahan daun delima ditunjukkan oleh tabel 4. Nilai porositas terkecil pada membran biofilter berbahan daun delima adalah $8.67 \%$ dengan variasi 0.7 gram. Tabel 5 menunjukkan hasil pengujian porositas membran biofilter dengan bahan biji delima. Nilai perositas terkecil terjadi pada variasi 0.7 gram dengan nilai porositas $4.10 \%$. Hasil pengujian nilai porositas pada membran biofilter berbahan kulit delima ditunjukkan oleh tabel 6. Pada tabel terlihat nilai porositas terkecil bernilai $76.72 \%$ dengan variasi 0.7 gram.

Tabel 4 Hasil Pengujian porositas membran biofilter berbahan daun delima

\begin{tabular}{ccccc}
\hline Membran $(\mathrm{g})$ & Massa Kering $(\mathrm{g})$ & Massa Basah $(\mathrm{g})$ & Volume $(\mathrm{ml})$ & Porositas $(\%)$ \\
\hline 0.7 & 1.06 & 1.12 & 0.692 & 8.67 \\
0.8 & 1.08 & 1.19 & 1.055 & 10.42 \\
0.9 & 1.11 & 1.29 & 1.105 & 16.29 \\
1 & 1.11 & 1.30 & 1.155 & 16.45 \\
\hline
\end{tabular}

Tabel 5 Hasil Pengujian porositas membran biofilter berbahan biji delima

\begin{tabular}{ccccc}
\hline Membran $(\mathrm{g})$ & Massa Kering $(\mathrm{g})$ & Massa Basah $(\mathrm{g})$ & Volume $(\mathrm{ml})$ & Porositas $(\%)$ \\
\hline 0.7 & 1.09 & 1.12 & 0.731 & 4.10 \\
0.8 & 1.13 & 1.24 & 0.846 & 13.002 \\
0.9 & 1.14 & 1.30 & 0.923 & 17.33 \\
1 & 1.16 & 1.34 & 1.205 & 14.93 \\
\hline
\end{tabular}

Tabel 6 Hasil Pengujian porositas membran biofilter berbahan daun delima

\begin{tabular}{ccccc}
\hline Membran $(\mathrm{g})$ & Massa Kering $(\mathrm{g})$ & Massa Basah $(\mathrm{g})$ & Volume $(\mathrm{ml})$ & Porositas $(\%)$ \\
\hline 0.7 & 1.10 & 1.69 & 0.769 & 76.72 \\
0.8 & 1.14 & 1.90 & 0.807 & 94.17 \\
0.9 & 1.20 & 2.03 & 0.846 & 98.11 \\
1 & 1.27 & 1.97 & 0.884 & 79.18 \\
\hline
\end{tabular}


Perbandingan porositas antara membran biofilter berbahan daun delima, biji delima dan kulit delima datunjukkan oleh gambar 2. Gambar ini menunjukkan bahwa porositas terkecil terletak pada membran biofilter dengan bahan biji delima variasi massa 0.7 gram. Nilai porositas terbesar adalah 76.72 pada membran biofilter berbahan kulit delima variasi 0.7 gram. Perbedaan ini disebabkan oleh komposisi yang terkandung dalam bahan yang membentuk membran biofilter juga berbeda. Semakin kecil nilai porositas membran biofilter makan akan semakin baik karena pori-pori membran kecil dan dapat menangkap radikal bebas semakin banyak.

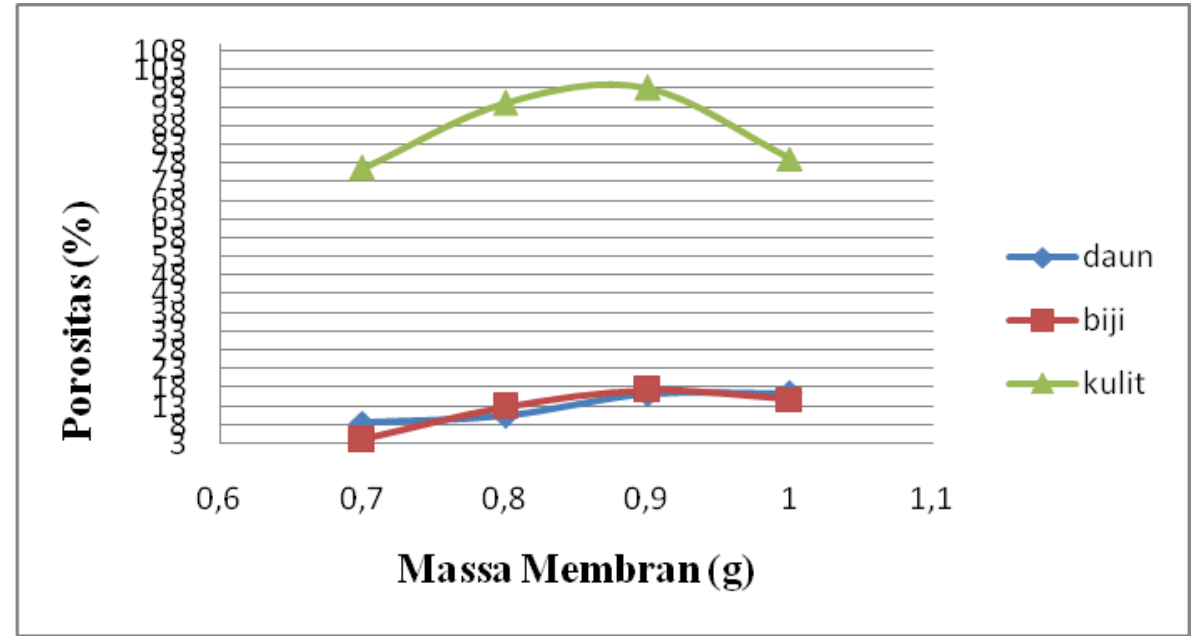

Gambar 2. Perbandingan nilai porositas membran biofilter berbahan daun delima, biji delima dan kulit delima.

Membran yang telah dibuat menggunakan variasi komposisi serbuk yang berbedabeda dengan ditambah PEG sebagai matriks menghasilkan karakteristik yang berbeda pula. Polietilen glikol (PEG) merupakan salah satu diantara zat aditif yang sering ditambahkan pada pembuatan membran yang berfungsi sebagai porogen untuk meningkatkan keteraturan bentuk pori-pori pada membran sehingga struktur pori lebih rapat dan membran yang dihasilkan semakin bagus.

Hubungan kerapatan dan porositas berbanding terbalik, semakin tinggi nilai kerapatan membran maka semakin rendah nilai porositas membran. Hal ini berarti semakin tinggi nilai kerapatan maka suatu membran tersebut pori-porinya semakin kecil dan rapat, sebaliknya jika nilai porositasnya tinggi maka suatu membran mempunyai pori-pori dan rongga yang lebar sehingga asap rokok yang melewati membran akan mudah dan jenis radikal bebas dari asap rokok akan sedikit yang dapat diserap oleh membran.

\section{KESIMPULAN}

Hasil nilai kerapatan membran komposit pada bahan serbuk daun delima dan biji delima menunjukkan nilai kerapatan tertinggi pada komposisi 0.7 gram, niali kerapatan pada daun delima adalah $1.532 \mathrm{~g} / \mathrm{cm}^{3}$, sedangkan nilai kerapatan biji delima adalah 1.491 $\mathrm{g} / \mathrm{cm}^{3}$. Sedangkan pada komposisi kulit delima menunjukkan nilai kerapatan yang baik adalah pada komposisi 1 gram dengan nilai $1.436 \mathrm{~g} / \mathrm{cm}^{3}$. Nilai porositas terendah pada massa serbuk daun dengan komposisi $0.7 \mathrm{~g}$ adalah $8.67 \%$. Nilai porositas terendah pada 
massa serbuk biji delima dengan komposisi $0.7 \mathrm{~g}$ adalah $4.10 \%$ dan nilai porositas terendah pada massa serbuk kulit buah delima dengan komposisi $0.7 \mathrm{~g}$ adalah $76.72 \%$.

\section{DAFTAR PUSTAKA}

(1) Yanjun Z, Dana K, Robert D. Rypo L. David W. International Multidimentional Authenticity Specification (IMAS) Algo rithm for Detection of Comercial Pomegranate Juice Adulteration. J. Agric Food Chem. 2009. 57(6): 2550-2557.

(2) Jones P M. Mechanics Of Composite Materials, Institute Of Technology, Southem Methodist University. Dallas: Mc Graw-Hill; 1975.

(3) Schwartz M M. Composite Materials Handbook. New York: Mc Graw-Hill; 1984.

(4) Agustina Siti dkk. Penggunaan Teknologi Membran Pada Pengolahan Air Limbah Industri Kelapa Sawit: Jurnal Penelitian pdf; 2006.

(5) Chooi Ong Hean. Buah Khasiat Makanan dan Ubatan. Kuala Lumpur: Taman Shamelin Perkasa; 2007.

(6) Santoso Hieronymus Budi. TOGA 2-Tanaman Obat Keluarga. Yogyakarta: Kanisius; 1998. 